\title{
Clonidine Vs Gabapentin Pre-treatment to Assess Attenuation of Pressor Response to Direct Laryngoscopy
}

\author{
Dr. P. Lavan Sagar ${ }^{1, *}$ and Dr.Vivek Chakole ${ }^{2}$ \\ 1'Department of Anaesthesiology, Jawaharlal Nehru Medical College ,Sawangi, Wardha, \\ Maharashtra, India; dr.lavansagar@gmail.com \\ 2Department of Anaesthesiology, Jawaharlal Nehru Medical College, Sawangi, Wardha, \\ Maharashtra, India; drvivekchakole@rediffmail.com
}

\begin{abstract}
Introduction: Direct larynges copy and intubation following induction of general anaesthesia is associated with reflex sympathetic discharge caused by epi-pharyngeal and laryngo-pharyngeal stimulation and release of catecholamines manifesting in tachycardia and hypertension. Various pharmacological agents and several supporting studies are available to attenuate this response. Aim: To compare the effect of oral premedication on cardiovascular response to direct laryngoscopy and endotracheal intubation with oral clonidine $150 \mu \mathrm{g}$ and oral gabapentin $800 \mathrm{mg}$. Material \& Methods: In this prospective randomized and double-blind study 80 patients of ASA class-I and II (American Society of Anesthesiologists) of age between 18-60 years were included. Patients were randomly and equally divided into group C and group $\mathrm{G}$ and received premedication with oral Clonidine $150 \mu \mathrm{g}$ and oral Gabapentin $800 \mathrm{mg}$ respectively. Monitoring of hemodynamic parameters such as blood pressure (systolic, diastolic and mean) and heart rate noted just before induction, and readings were recorded before intubation and also postintubation at 1, 3, 5, and $10 \mathrm{~min}$. Statistical analysis was done using SPSS17.0. Results: Premedication with oral clonidine $150 \mu \mathrm{g}$ and oral gabapentin $800 \mathrm{mg}$, both are effective in blunting pressor response to laryngoscopy and endotracheal intubation. Oral premedication with Clonidine was more effective than premedication with oral gabapentin for controlling pressor response associated with laryngoscopy and tracheal intubation. Conclusion: Oral premedication by both the drugs can be used as an effective measure to attenuate the reflex sympathetic response to direct laryngoscopy and endotracheal intubation, but clonidine is more effective than gabapentin.
\end{abstract}

Keywords: Clonidine, Gabapentin, Pressor Response, Laryngoscopy, Intubation.

\section{Introduction}

Direct larynges copy leads to haemodynamic stress responses in the form of tachycardia and hypertension. Pressor response to direct laryngoscopy and endotracheal intubation is due to mechanical stimulation of larynx and trachea causing a reflex sympathetic response. Following larynges copy for intubation, plasma catecholamines concentration increases $\underline{1}$ and there may be associated complications such as myocardial ischemia and cerebral haemorrhage ${ }^{2}$. Earlier to attenuate these responses, premedication such as vasodilators, $\underline{3}$ adrenoreceptor blockers, $\underline{4}$ calcium channel blocker $\underline{5}, \underline{6}$ andopioids $-\underline{7}-\underline{10}$ were used with variable results.

Clonidine is an $\alpha-2$ agonist with properties of central sympatholytic effect. Clonidine premedication blunts pressor response to laryngoscopy and intubation. Clonidine also increases cardiac baroreceptor reflex sensitivity, thus stabilizes blood pressure. $\underline{\underline{11}}$

${ }^{*}$ Author for correspondence 
Gabapentin, 1-(aminomethyl) cyclohexane acetic acid, is a structural analogue of GABA ( $\gamma$-aminobutyric acid) neurotransmitter. It is an anticonvulsant drug. $\underline{12}$ Gabapentin is selectively binding to the $\alpha 2 \delta$ subunit of voltage-dependent $\mathrm{Ca}^{2+}$ channels (VGCCs) and modulates $\mathrm{Ca}^{2+}$ current. Thus it may have properties similar to that of calcium channel blockers. $.13,14$ Thus gabapentin pretreatment can prevent the development of hyperalgesia and blunts the hypertensive response to intubation.

\section{Materials and Method}

This prospective, double-blind, randomized study was carried out at the Anaesthesiology department, Jawaharlal Nehru Medical College, Datta Meghe Institute of Medical Sciences (DMIMS) and Acharya Vinoba Bhave Rural Hospital, Sawangi, (Wardha) Maharashtra.

This study was carried out after obtaining approval from the Institutional Ethics Committee. Written informed consent was obtained from eighty patients, under ASA class I and II (American Society of Anesthesiologists), aged between 18-60 years, posted for elective surgery requiring general anaesthesia. Patients with systemic disorder like uncontrolled hypertension, diabetes, seizure disorder, respiratory disorders, kidney or liver disease, coronary artery disease, recent history of myocardial infarction, patients on regular medication of Tricyclic antidepressants (TCA), Selective serotonin reuptake inhibitor (SSRI), Monoamine oxidase inhibitors or opioids, patients with any known allergy or hypersensitivity for drugs to be used, obese patients, anticipated difficult airway and pregnant women were excluded from this study.

Patients of this study were randomly assigned to study groups using a computer-generated randomization table. Each study group included 40 patients. Group 'C' received Tab.

Clonidine $150 \mu$ g orally and group 'G' received Tab. Gabapentin $800 \mathrm{mg}$ orally. These premedications are given 90 min prior to induction. The administration of study drugs was done in a double-blind fashion.

After shifting the patient into the operating room, under aseptic precaution, intravenous cannula (18G) is placed in an appropriate vein. Ringers' lactate solution is started intravenously. A monitor attached to the patient includes pulse oximetry $\left(\mathrm{SPO}_{2}\right)$, electrocardiography
(ECG) and an automated BP cuff. Heart rate (HR), Systolic, diastolic and mean arterial blood pressure (SBP, DBP, MAP) were measured as baseline values at the preinduction time.

Pre-oxygenation done for 3 minutes, i.v. glycopyrolate $0.004 \mathrm{mg} / \mathrm{kg}$, i.v. midazolam $0.05 \mathrm{mg} / \mathrm{kg}$, i.v. but orphanol $0.04 \mathrm{mg} / \mathrm{kg}$ given, then induction done with i.v propofol $2 \mathrm{mg} / \mathrm{kg}$ followed by i.v. vecuronium $0.1 \mathrm{mg} / \mathrm{kg}$ given. Manual ventilation with $100 \%$ oxygen is done for 3 minutes. Direct laryngoscopy performed with appropriate laryngoscope blade and endotracheal intubation was accomplished within 15 seconds, by using appropriate sized endotracheal tube.

Inhalational agent sevoflurane, of Minimum alveolar concentration (MAC) of $1.7 \%$ and nitrous oxide $\left(\mathrm{N}_{2} \mathrm{O}\right)$ of $60 \%$ in oxygen $\left(\mathrm{O}_{2}\right)$ were used to maintain anaesthesia. Patients were ventilated mechanically. Minute ventilation adjusted according to end-tidal carbon dioxide levels $\left(\mathrm{EtCO}_{2}\right.$ between 35 to $\left.40 \mathrm{mmHg}\right)$ to maintain normocapnia. Neuromuscular blockade is supplemented with vecuronium $0.02 \mathrm{mg} / \mathrm{kg}$, every 20 minutes to maintain muscle relaxation.

Heart rate and blood pressure (SBP, DBP, and MAP) were measured prior to induction, just beforelaryngoscopy and following intubation (i.e. immediately after intubation and at 1, 3, $5 \& 10$ minutes post laryngoscopy).

At the end of surgery, the inhalational agent is discontinued. Patient supplied with 100\% oxygen and residual neuromuscular block antagonized with neostigmine $(0.05 \mathrm{mg} / \mathrm{kg})$ and glycopyrrolate $(0.01$ $\mathrm{mg} / \mathrm{kg}$ ). Extubation performed after recovery from anaesthesia.

The statistical analysis was done using SPSS (Statistical Package for Social Sciences) Version 17.0 statistical Analysis Software. The value of results was represented in Number (n) and Mean with standard deviation (Mean \pm $\mathrm{SD})$.

\section{Results}

All the patients were comparable in both the study groups with respect to demographic profile (i.e., age, gender, and body weight) and also statistically, no significant difference was found in baseline haemodynamic values of both the study groups.

However, we found that after oral premedication, systolic blood pressure (SBP) of patients among Clonidine 
Group was better controlled when compared to those of Gabapentin Group throughout the study period which was statistically significant at 1 minute and at 3 minutes post-intubation ( $\mathrm{p}=0.032$ and $\mathrm{p}=0.008$ respectively) Table 1.

Diastolic blood pressure (DBP) of patients, who received premedication with clonidine (Group-C) was found lower than those who received gabapentin (Group-G) at all the observation periods. This difference was statistically significant at all the periods of observation ( $\mathrm{p}<0.05)$ except at 10-minute post-intubation Table 2.

Mean arterial pressure (MAP) was found to be lower among the clonidine group than that of the gabapentin group. Statistically, this difference was found to be significant at all observation periods $(\mathrm{p}<0.05)$ except at 10 minute post-intubation ( $\mathrm{p}=0.116$; NS) Table 3 .

Throughout the study period heart rate (HR) of group-C (clonidine) when compared to group-G (gabapentin) was found to be lower. However, statistically, this difference was found significant immediately following intubation $(p<0.001)$, whereas not significant for the rest of the study period Table 4 .

\section{Discussion}

This prospective, randomized, double-blind study was conducted to compare the effects of oral premedication

Table 1. Systolic blood pressure, SBP ( $\mathrm{mm} \mathrm{Hg}$ ) at different intervals of study period

\begin{tabular}{|l|c|c|c|c|c|}
\hline \multirow{2}{*}{$\begin{array}{l}\text { Time } \\
\text { interval }\end{array}$} & \multicolumn{2}{|c|}{$\begin{array}{c}\text { Group - C } \\
\text { (clonidine) N }\end{array}$} & \multicolumn{2}{c|}{$\begin{array}{c}\text { Group - G } \\
\text { (gabapentin) } \\
\text { N }=40\end{array}$} & (p-value) \\
\cline { 2 - 5 } & Mean & \pm SD & Mean & \pm SD & \\
\hline $\begin{array}{l}\text { Pre- } \\
\text { induction }\end{array}$ & 118.04 & 12.81 & 121.44 & 4.14 & 0.114 \\
\hline $\begin{array}{l}\text { After } \\
\text { induction }\end{array}$ & 115.11 & 13.24 & 118.96 & 3.46 & 0.079 \\
\hline $\begin{array}{l}\text { Immediately } \\
\text { after } \\
\text { intubation }\end{array}$ & 117.01 & 15.54 & 120.91 & 4.00 & 0.128 \\
\hline After 1min & 117.41 & 14.94 & 122.74 & 3.97 & 0.032 \\
\hline After 3min & 113.96 & 11.72 & 119.31 & 4.36 & 0.008 \\
\hline After 5min & 113.34 & 13.89 & 116.51 & 4.52 & 0.173 \\
\hline After 10min & 115.66 & 13.66 & 117.34 & 4.35 & 0.460 \\
\hline
\end{tabular}

$n$ - Number of patients.

SD - Standard deviation.

$\mathrm{p}<0.05$ (S-statistically significant)

p $>0.05$ (NS-statistically not significant).
Table 2. Diastolic blood pressure, DBP ( $\mathrm{mm} \mathrm{Hg})$ at different intervalsof study period

\begin{tabular}{|l|c|c|c|c|c|}
\hline \multirow{2}{*}{$\begin{array}{l}\text { Time } \\
\text { interval }\end{array}$} & \multicolumn{2}{|c|}{$\begin{array}{c}\text { Group - C } \\
\text { clonidine) (n } \\
=\mathbf{4 0})\end{array}$} & \multicolumn{2}{c|}{$\begin{array}{c}\text { Group - G } \\
\text { (gabapentin) } \\
(\mathbf{n}=\mathbf{4 0})\end{array}$} & \multirow{2}{*}{ (p-value) } \\
\cline { 2 - 5 } & Mean & \pm SD & Mean & \pm SD & \\
\hline $\begin{array}{l}\text { Pre- } \\
\text { induction }\end{array}$ & 72.69 & 11.36 & 78.29 & 3.33 & 0.003 \\
\hline $\begin{array}{l}\text { After } \\
\text { induction }\end{array}$ & 69.84 & 11.47 & 76.46 & 3.18 & $<0.001$ \\
\hline $\begin{array}{l}\text { Immediately } \\
\text { after } \\
\text { intubation }\end{array}$ & 71.21 & 14.76 & 78.29 & 3.87 & 0.004 \\
\hline After 1min & 73.86 & 14.83 & 79.29 & 3.31 & 0.026 \\
\hline After 3min & 68.24 & 10.23 & 76.19 & 3.40 & $<0.001$ \\
\hline After 5min & 68.36 & 13.67 & 72.91 & 2.71 & 0.042 \\
\hline After 10min & 69.54 & 13.61 & 73.26 & 2.65 & 0.093 \\
\hline
\end{tabular}

Table 3. Mean arterial pressure, MAP $(\mathrm{mm} \mathrm{Hg})$ at different intervalsof study period

\begin{tabular}{|l|c|c|c|c|c|}
\hline \multirow{2}{*}{$\begin{array}{l}\text { Time } \\
\text { interval }\end{array}$} & \multicolumn{2}{|c|}{$\begin{array}{c}\text { Group - C } \\
\text { clonidine) (n } \\
=\mathbf{4 0})\end{array}$} & \multicolumn{2}{c|}{$\begin{array}{c}\text { Group - G } \\
\text { (gabapentin) } \\
=4 \mathbf{4 0}\end{array}$} & (p-value) \\
\cline { 2 - 5 } & Mean & \pm SD & Mean & \pm SD & \\
\hline $\begin{array}{l}\text { Pre- } \\
\text { induction }\end{array}$ & 87.29 & 11.64 & 92.69 & 3.30 & 0.006 \\
\hline $\begin{array}{l}\text { After } \\
\text { induction }\end{array}$ & 84.14 & 11.48 & 90.71 & 2.90 & $<0.001$ \\
\hline $\begin{array}{l}\text { Immediately } \\
\text { after } \\
\text { intubation }\end{array}$ & 86.46 & 14.45 & 92.56 & 3.46 & 0.011 \\
\hline After 1min & 87.74 & 14.58 & 93.79 & 3.17 & 0.012 \\
\hline After 3min & 82.76 & 10.18 & 90.61 & 3.22 & $<0.001$ \\
\hline After 5min & 82.91 & 13.43 & 87.39 & 2.74 & 0.042 \\
\hline After 10min & 84.39 & 13.79 & 87.91 & 2.61 & 0.116 \\
\hline
\end{tabular}

of clonidine $(150 \mu \mathrm{g})$ versus Gabapentin $(800 \mathrm{mg})$ on pressor response to laryngoscopy and intubation.

Regarding the comparison of the efficacy of oral premedication with clonidine and gabapentin for attenuating cardiovascular stress response to laryngoscopy and tracheal intubation, there are only a few studies are available in the literature.

Studied premedication efficacy of oral gabapentin with two different doses of $800 \mathrm{mg}$ and $400 \mathrm{mg}$. Study results showed that the patients in group receiving $800 \mathrm{mg}$ had 
Table 4. Heart rate, HR (per minute) at different intervalsof study period

\begin{tabular}{|l|c|c|c|c|c|}
\hline \multirow{2}{*}{$\begin{array}{l}\text { Time } \\
\text { interval }\end{array}$} & \multicolumn{2}{|c|}{$\begin{array}{c}\text { Group - C (n } \\
\mathbf{4} \mathbf{4 0})\end{array}$} & \multicolumn{2}{c|}{$\begin{array}{c}\text { Group - G } \\
(\mathbf{n = 4 0})\end{array}$} & $\begin{array}{c}\text { Statistical } \\
\text { significance } \\
\text { (p-value) }\end{array}$ \\
\cline { 2 - 5 } & Mean & $\mathbf{\pm S D}$ & Mean & $\mathbf{\pm S D}$ & \\
\hline Pre-induction & 78.03 & 15.80 & 80.56 & 5.43 & 0.341 \\
\hline $\begin{array}{l}\text { After } \\
\text { induction }\end{array}$ & 75.49 & 16.72 & 77.71 & 5.64 & 0.428 \\
\hline $\begin{array}{l}\text { Immediately } \\
\text { after } \\
\text { intubation }\end{array}$ & 73.29 & 14.68 & 83.01 & 4.79 & $<0.001$ \\
\hline After 1min & 81.36 & 12.96 & 82.46 & 5.29 & 0.620 \\
\hline After 3min & 76.29 & 13.31 & 78.01 & 5.18 & 0.448 \\
\hline After 5min & 73.01 & 13.67 & 74.67 & 5.45 & 0.477 \\
\hline After 10min & 70.66 & 13.23 & 70.81 & 5.73 & 0.947 \\
\hline
\end{tabular}

a significant reduction in pressor response due to direct laryngoscopy and tracheal intubation.

In $\underline{15}$ conducted a placebo-controlled, doubleblind, randomized study for comparing the efficacy of oral gabapentin $900 \mathrm{mg}$ and oral clonidine $200 \mu \mathrm{g}$ as premedication, to blunt the pressor response to direct laryngoscopy and intubation among patients posted for elective orthopaedic surgeries. Patients were premedicated with study drugs, 2 hours prior to posted surgery as per the respective group. The author of this study concluded that oral premedication with both gabapentin and clonidine has an effective role in blunting the cardiovascular stress response following Laryngoscopy and Intubation, but more so with gabapentin. In our study, clonidine has a better response than gabapentin in blunting the hemodynamic response following Laryngoscopy and Intubation.

In $\underline{16}$ studied the comparison of oral gabapentin $800 \mathrm{mg}$ and oral clonidine $200 \mu \mathrm{g}$ as premedication to attenuate the laryngoscopic stress response. Although we considered a lower dose of clonidine $(150 \mu \mathrm{g})$, our study results are comparable to them that clonidine is better than gabapentin for blunting reflex sympathetic response to laryngoscopy and endotracheal intubation.

\section{Conclusion}

We found that oral premedication with both clonidine $(150 \mu \mathrm{g})$ and gabapentin $(800 \mathrm{mg})$ is effective in blunting reflex sympathetic stress response to direct laryngoscopy and intubation. However, oral clonidine compared to oral gabapentin was found to be more effective in blunting changes in blood pressure and heart rate associated with pressor response to direct laryngoscopy and intubation. In order to establish the safety and efficacy of these two drugs in patients of extreme age groups and those patients with co-morbid conditions, further studies are needed.

\section{References}

1. Russell WJ, Morris RG, Frewin DB, Drew SE. Changes in plasma catecholamine concentrations during endotracheal intubation. Br J Anaesth. 1981;53(8):837-9.

2. Edwards ND, Alford AM, Dobson PM, Peacock JE, Reilly CS. Myocardial ischaemia during tracheal intubation and extubation. Br J Anaesth. 1994:73(4):537-9.

3. Fassoulaki A, Kaniaris P. Intranasal administration of nitroglycerine attenuates the pressor response to laryngoscopy and intubation of the trachea. Br J Anaesth. 1983;55(1):49-52.

4. Miller DR, Martineau RJ, Wynands JE, Hill J. Bolus administration of esmolol for controlling the haemodynamic response to tracheal intubation: the Canadian Multicentre trial. Can J Anesth. 1991;38(7):849-58.

5. Kale SC, Mahajan RP, Jayalakshami TS, Raghavan V, Das B. Nifedipine prevents the pressor response to laryngoscopy and tracheal intubation in patients withcoronary artery disease. Anaesthesia. 1988;43(6):495-7.

6. Mikawa K, Ikegaki J, Maekawa N, Goto R, Kaetsu H, Obara $\mathrm{H}$. The effect of diltiazem on the cardiovascular response to tracheal intubation. Anaesthesia.1990;45(4):289-93.

7. Dahlgren N, Messeter K. Treatment of stress response to laryngoscopy and intubation with fentanyl. Anesthesia. 1981;36:1022-6.

8. Miller DR, Martineau RJ, O'Brien H, et al. Effects of alfentanil on the haemodynamic and catecholamine response to tracheal intubation. Anesth Analg. 1993;76:1040-6.

9. Korpien R, Sarnivaara L, Siren K, Sarna S. Modification of the haemodyamic responses to induction of anaesthesia and tracheal intubation with alfentanil, esmolol and their combination. Can J Anesth. 1995;42:298-304.

10. McAtamney D, O’Hare R, Hughes D, Carabine U, Mirakhur R. Evaluation of remifentanil for control of haemodynamic response to tracheal intubation. Anaesthesia. 1998;53(12):1223-7.

11. Singh S, Arora K. Effect of oral clonidine premedication on peri operative haemodynamic response and postoperative analgesic requirement for patient sunder going laparoscopic cholecystectomy. Indian J Anaesth. 2011;55(1):26-30.

12. Turan A, Kaya G, Karamanlioglu B, Pamukcu Z, Apfel CC. Effects of oral gabapentin on postoperative analgesia. Br J Anaesth. 2006;96:242-6. 
13. Memis D, Turan A, Karamamlioglu B, Seker S, Ture M. Gabapentin reduce cardiovascular responses to laryngoscopy and tracheal intubation. Eur J Anaesthesiol. 2006;23:686-90.

14. Fassoulaki A, Melemeni A, Paraskeva A, Petropoulos G. Gabapentin attenuates the pressor responses to direct laryngoscopy and tracheal intubation. Br J Anaesth. 2006;96:769-73.

15. Marashi SM, Ghafari MH, Saliminia A. Attenuation of hemodynamic responses following laryngoscopy and tracheal intubation--comparative assessment of clonidine and gabapentin premedication. Middle East J Anesthesiol. 2009;20:233-7.

16. Majumdar S, Das A, Das H, Bandyopadhyay S, Hajra BK, Mukherjee D. Comparative evaluation of oral gabapentin versus clonidine as premedication on preoperative sedation and laryngoscopic stress response attenuation for the patients undergoing general anesthesia. Perspect Clin Res. 2015;6:211-6. 